


\title{
National security policy: Changing priorities in the face of the COVID-19 threat
}

\section{DOI: https://doi.org/10.46398/cuestpol.3969.47}

\author{
Petro P. Pidyukov * \\ Alexander G. Kolb ** \\ Oleh V. Batiuk *** \\ Ihor H. Kudria **** \\ Larysa S. Tarasiuk *****
}

\begin{abstract}
This article analyzes institutional, procedural, and behavioral attributes, principles, and indicators of typology of challenges and threats caused by the coronavirus pandemic in the world. The analysis shows that most countries faced external shocks caused by COVID-19 in the absence of a universal social protection system, a reliable health system, a plan to achieve carbon neutrality by 2050, or a stable real economy with quality jobs. Economic security has become an important priority, although this is not about social protection, but also about supporting strategic sectors of the economy. Balancing on the brink of the needfor socialprotection, on the one hand, and the rise of austerity, on the other, governments opted for severe economic restrictions. Thus, through the naaliticos method the authors describen the main geopolitical trends that will be the basis for the construction of a new world order that awaits us on the other side of the pandemic, including deglobalization, the geopolitical rise of China, the severe restrictions on human and civil rights, the intensification of the interstate armed forces, in context of growing
\end{abstract} conflicts and local protests.

* Doctor in Law, Professor, Senior Researcher, Unit for the Organization of Scientific Activity and Protection of Intellectual Property Rights, National Academy of Internal Affairs. ORCID ID: https:// orcid.org/oooo-0002-9831-845X. Email: tatust180679@gmail.com

** Doctor in Law, Professor, Departament of Political Science and Public Administration, Lesya Ukrainka Volyn National University. ORCID ID: https://orcid.org/oooo-00o3-1792-4739. Email: alexanderko3132@gmail.com

*** PhD in Law, Associate Professor, Departament of Political Science and Public Administration, Lesya Ukrainka Volyn National University. ORCID ID: https://orcid.org/oooo-0oo2-2291-4247. Email: olegbatiukibpnt@gmail.com

**** Doctor of Philosophy, Associate Professor, Departament of Philosophy and History, V. I. Vernadsky Taurida National University. ORCID ID: https://orcid.org/oooo-ooo2-4324-1336. Email: ikudrya76@ gmail.com

***** Doctor of Philosophy, Associate Professor, Departament of Philosophy and History, V. I. Vernadsky Taurida National University. ORCID ID: https://orcid.org/oooo-0002-3863-7707. Email: loraa253@ gmail.com 
Keywords: national security; national interests; COVID-19; pandemic threats; global transformations.

\section{Política de Seguridad Nacional: Cambiar las prioridades frente a la amenaza del COVID-19}

\section{Resumen}

Este artículo analiza atributos, principios e indicadores institucionales, procedimentales y de comportamiento de tipología de desafíos y amenazas provocados por la pandemia de coronavirus en el mundo. El análisis muestra que la mayoría de los países enfrentaron choques externos causados por COVID-19 en ausencia de un sistema de protección social universal, un sistema de salud confiable, un plan para lograr la neutralidad de carbono para 2050 o una economía real estable con empleos de calidad. La seguridad económica se ha convertido en una prioridad importante, aunque no se trata de protección social, sino ademas de apoyar sectores estratégicos de la economía. Al equilibrarse al borde de la necesidad de protección social, por un lado, y el surgimiento de la austeridad, por el otro, los gobiernos optaron por severas restricciones económicas. Así, mediante el metodo naaliticos los autores describen las principales tendencias geopolíticas que serán la base para la construcción de un nuevo orden mundial que nos espera al otro lado de la pandemia, incluida la desglobalización, el ascenso geopolítico de China, las severas restricciones a los derechos humanos y civiles, la intensificación de las fuerzas armadas interestatales, en context de creciente conflictos y protestas locales.

Palabras clave: seguridad nacional; intereses nacionales; COVID-19; amenazas pandémicas; transformaciones globales.

\section{Introduction}

The research topicality is due to awareness of the nature of threats, i.e., their origin, occurrence, and development. The fact is that we can talk about threats only when national interests are clearly determined. Threats are certain factors that arise in the environment of the object, and their occurrence is directly related to the realization of national interests. Thus, threats hinder both the creation of conditions for the realization of interests, and national interests directly. On this basis we can conclude that the threat appears where and when there are clearly determined national interests and real steps are being undertaken to implement them. 
Petro P. Pidyukov, Alexander G. Kolb, Oleh V. Batiuk, Ihor H. Kudria y Larysa S. Tarasiuk
758 National security policy: Changing priorities in the face of the COVID-19 threat

In our earnest conviction, national security is, first of all, the protection of the vital interests of the nation. And any detail about objects, subjects, principles of provision, priorities and threats to national interests, national security policy, etc. is an extremely complex professional intellectual process, which should be carried out not by situationally selected politicians, but by experienced applied scholars through constant consultations with all stakeholders.

The research objective is to carry out the typology of risks to national security caused by the growing degree of pandemic threats; outline the key geopolitical trends which will be the basis for building the new world order. Another objective was to analyse the structural problems that have led to the vulnerability of the national security system.

The following targets were set to achieve these objectives:

- substantiate fundamentally new theoretical approaches to ensuring national security at the present stage.

- $\quad$ study the world practice of global rating assessment of the stability of society and the state in the period of pandemic threats.

- develop an algorithm for the implementation of a modern system of comprehensive assessment of the state of national security based on the analysis of the best international practices in the field of monitoring of key international indices.

\section{Literature review}

A fundamental issue in the study of security problems is the distinction between such important and fundamental categories as national security and national interests. Without realizing the fundamental differences between them, we are doomed to constant hopeless scientific search.

According to Becker, Mölling and Schütz (2020) there are the results of understanding the values of the existence of a nation. A nation does not exist without national interests, it becomes a population, the people are an "open society" living in a certain area and meeting their basic needs. National interests indicate that the nation identifies itself as such, it separates itself from other nationalities or ethnic groups, and most importantly it proclaims the intention to continue to exist and gradual develop in its own way based on its own historical traditions and way of life (Barno and Bensahel, 2020).

According to Hegel (2001), only historical nations have the opportunity to further develop and preserve a holistic identity in the context of global transformations of worldviews and configurations of pandemic threats. 
In turn, the representatives of the public administration science (Finley et al., 2020) define national security as a type of social activity, the main purpose of which is to create favourable conditions for the realization of these interests. Therefore, national security can be seen as a national interest.

As Sussman (2019) points out, there is every reason to believe that the lack of clearly determined national interests that are inseparable from the goals of the nation and do not express the will of the ruling political force undermines the idea of national security and real sustainable development. The scientific approach that involves levelling the process of self-reflection of the state's interests is conceptually erroneous. This quasi-scientific discussion arises where and when there is no methodology for considering and researching the issue.

In this case, state interests are an ambivalent category: 1) on the one hand, they express the interests of the state apparatus itself (any official is interested in retaining the position of his immediate superior, because in this case he will also remain in office, etc.); 2) on the other hand, they accumulate the needs of society and the individual, because the state is the most effective organization of civil society and has a mechanism that can guarantee the realization of human rights and freedoms. In this permanent conflict, many researchers ignore security issues, especially in the field of state security, where the latter is unacceptable and identified with the security of the state.

In March 2020 Susskind called the catastrophe caused by the COVID-19 coronavirus infection "the closest thing to revelation from the point of view of atheists" (Susskind, 2020: 320). It reflects the biblical feeling of shock that many people felt during the sudden, deep, rapidly growing crisis. "We have been going with the stream for more than half a century," the rabbi said, "and suddenly we faced with a fragile and vulnerable humanitarian situation" (Susskind, 2020: 320). The current crisis caused by coronavirus infection poses a threat to national security, as it has a number of new, unfamiliar properties. The rapid spread of the virus, which is still unexplored, is leading to a global humanitarian crisis.

After the end of the COVID-19 pandemic, the world is unlikely to become the same (Lund et al., 2020). Under the influence of the pandemic, many threats to the stability of the world order, which have already emerged, continue to grow. This is especially true of the development of the digital economy against the background of increasing the use of digital technologies, including for distance work and distance learning. Moreover, other structural changes, such as regionalization of supply chains and further growth of cross-border data flows, may accelerate. The future has come too quickly, bringing, and possibly multiplying, a number of problems such as income polarization, workers' vulnerability, an increase 
in the number of short-term contracts and the need for workers to adapt to changing activities. These accelerated processes are the result not only of scientific and technological progress, but also of new circumstances that have arisen in connection with the threat to public health and safety, so the economy of the countries and labour markets need time to recover, and there is a high probability that they undergo a number of changes as a result.

As the impact of these trends grows, the realities of the current crisis have led to a revision of a number of existing beliefs that can influence long-term decisions in the field of national security (Sussman, 2019). This applies to views on the relationship between efficiency and sustainability of increasing concentration of economic activity and life, industrial policy, approaches to problems that affect all countries and require collective action on a global scale (e.g. armed conflicts, pandemics and climate change), as well as changes in the role of governments and different governance institutions. Over the last two decades, in developed economies, responsibility has generally shifted from institutions to citizens. However, inspections of health systems often reveal their ineffectiveness, and such concepts of social benefits as paid sick leave or the required subsistence level are drawing attention again.

According to Fleming (2020), there is a possibility of long-term changes in the formation of approaches to providing civil society institutions with a more inclusive form of common agreement through social protection systems. As history has shown, the decisions made during the crisis can determine the situation in the world for decades to come. At the same time, the need to take collective measures for the development of the state security system, which will ensure comprehensive economic growth, prosperity, and general security, remains fundamentally important.

Bietti et al. (2020: 39) wrote: "Historically, the situation was such that pandemics forced people to say goodbye to the past and look at the world in a new way. It is a portal, or a gate between one world and another." The existing multilateral system has to undergo a number of changes in order to bring it into line with this completely new world.

According to Philips (2020), the COVID-19 pandemic continues to test the limits of global cooperation opportunities. In particular, the level of support of developing countries remains very low. They suffered from the global economic downturn in the early stages of the pandemic, including due to record capital outflows and deteriorating financial conditions. In the context of a severe humanitarian crisis, the extremely limited budgetary capacity of these countries is under unprecedented pressure due to the necessity to meet the needs of health and social protection systems. The decisions taken now will have far-reaching consequences. Maintaining the line of policy unchanged would be unjustified and would ignore the scale of the human suffering caused by the pandemic. 
As part of an appropriate UN-led reform program, the IMF must be involved in addressing the structural problems that have led to the vulnerability of developing countries in terms of debt. Such a reform agenda should provide for the gradual abandoning of the use of funds allocated for the development in order to carry out reforms aimed at improving the market and creating incentives to attract private investment. It is also necessary to abandon the dogmas of austerity. Besides, rich countries must finally begin to meet their official development assistance commitments. The imbalance of power within international institutions also needs to be corrected to ensure fair recognition of the needs and rights of two-thirds of the world's population living in third world countries. If the international community fails to respond immediately and decisively to the situation, the implementation of the 2030 Agenda and the Paris Agreement will inevitably be disrupted. A new multilateral system in which the reform of the Bretton Woods Institutions will play a key role is needed now and must be based on an approach to development that gives priority to human rights, gender equality and climate issues.

Fukuyama (2020) notes that after the end of the first wave of COVID-19 the world must become more inclusive, sustainable and viable. Today we live in a world, where inequality between countries and regions within countries within countries has increased as a result of competition for legislative concessions in the field of business regulation, as well as in connection with poverty among a large part of the world's labour force. Many countries have faced external shocks caused by COVID-19 coronavirus infection in the absence of a universal social protection system, a robust health care system, a plan to achieve carbon neutrality by 2050 or a sustainable real economy with quality jobs. The Bretton Woods Conference, held at a time when the war was still ongoing, helped lay the groundwork for a post-war common agreement. Similarly, the author proposes to develop an ambitious reconstruction plan, while we continue to take steps to stop the pandemic.

According to Slaughter (2020), international assistance is a matter of collective survival and investment in the future of health care, the global economy and multilateralism. The choice is ours, while the actions of the IMF and the multilateral system will be crucial. Our goal must be to achieve full employment and a new common agreement to restore global economic security. Public investment in social care services, education and lowcarbon infrastructure can provide an incentive to reduce inequality.

The COVID-19 pandemic, which has caused lasting change and gave the world a number of important lessons, will have lasting consequences for the world order. Screening for the virus is likely to be a part of our lives, just as increased security measures have become commonplace since the terrorist attacks of September 11, 2001. Countries need to invest in infrastructure designed to detect future outbreaks of the virus, Shevchuk and Mentuh 
(2020) believe. Such investment will protect the economy if the population's immunity to COVID-19 is temporary.

Variants of the German part-time employment program (Verordnung über die Bezugsdauer für das Kurzarbeitergeld) were adopted in many countries during the pandemic. This program ensures the preservation of jobs by reducing working hours and wages, while the government compensates for the loss of wages. The grounds for the implementation of the precautionary measures provided for in the Verordnung über die Bezugsdauer für das Kurzarbeitergeld program are the following:

- If a job loss is accompanied by a loss of earnings, a job loss is significant if it is based on economic reasons and is temporary and inevitable.

- Job loss can be avoided if it is mainly seasonal, common to the company or industry, based solely on organizational reasons, and can be fully or partially retained with leave.

- In the relevant calendar month (entitlement period), at least one third of the company's employees suffer loss of earnings in excess of $10 \%$ of their gross monthly earnings.

- The employer's notice must be accompanied by a statement from the trade union, if any.

By maintaining labour relations between companies and employees, the economy will be better prepared for a rapid recovery. Mechanisms for implementing such programs should be improved and become part of the existing set of tools for economic recovery. Distance work is likely to become more widespread. Evidence that working from home is at least as effective as working in the office has existed before, Friedrich-Vache and EndresReich (2020) say. However, many companies opposed the transition to distance work. Now, when many companies have successfully tested this model, distance work may become standard practice. The crisis of the pandemic has accelerated the process of transition to digital technologies, which is reflected in the further spread of e-commerce and increasing pace of implementation of telemedicine, video conferencing, distance learning and financial technology. Companies accustomed to relying on international supply systems have faced supply shortages and other difficulties. It is likely that many of these companies will soon return some of their production previously moved overseas to their home countries. Unfortunately, this trend will not create many jobs, as a major part of production is likely to be automated. Governments, which became the insurers and investors of last resort during the crisis, now play a more important role. Public debt will grow rapidly, creating financial problems around the world. 


\section{Methods and Materials}

As the focus of the study is changing priorities in the face of the Covid-19 threat, national security policy, the main elements of the mechanism of ensuring national security are studied through conceptual analysis.

The basic material of the theoretical research included regulatory documents and scientific publications. The research uses general scientific methods of empirical research, logical methods and research techniques: analysis of regulations and trends in national security indicators. Crossnational analysis allowed distinguishing such important and fundamental categories as national security and national interests, cross-temporal analysis of the interwar, post-war and modern period of formation of mechanisms for protection of national security in the period of pandemic threats. The institutional and political attributes, types and consequences of establishing key priorities in joint actions to overcome the crisis caused by the new coronavirus pandemic have been identified and analysed.

In addition, the research used transitological theories, which allowed to comprehensively, from different angles, consider the peculiarities of legal relations that arise between government agencies in order to ensure national security. Besides, the work is also reach in specific research tools of modern political science, especially in the form of comprehensive qualitative and quantitative methods of analysis.

\subsection{Research Design}

The study was carried out in several stages, each stage aimed at achieving the relevant analytical target. Upon achieving the targets at each stage of the study the intermediate results were systematized, and in the final phase of the study the overall results were tested using empirical data processing methods.

According to the scheme of scientific research, at the first stage (May - June 2020), we analysed the philosophical, psychological, political, medical, international and legal results of scientific research to study existing scientific approaches to the concept of "national security policy", as well as systematized threats, risks and restrictions of human rights during the pandemic, as the problem of national security is on the border of many scientific fields. At the next stage (July - August 2020), the authors formed their own vision of foreign policy priorities for the protection of national security and the foundations of the world order. The final stage (September 2020) was marked by the preparation of reasoned conclusions, which were the result of long scientific research. 
Petro P. Pidyukov, Alexander G. Kolb, Oleh V. Batiuk, Ihor H. Kudria y Larysa S. Tarasiuk
764 National security policy: Changing priorities in the face of the COVID-19 threat

\section{Results}

While the world's population is anxiously watching the rapid spread of the SARS-CoV-2 coronavirus, which has killed about 131,00o people worldwide, we are witnessing another dangerous trend that will cause many social unrest, riots and even armed conflicts in the future. It is the destruction of the world order from the inside - a violation of human and civil rights. According to Amnesty International, governments in many countries, including Eastern Europe, use the pandemic as an excuse to restrict the rights of their own citizens, as well as migrants seeking to cross EU borders.

On April 15, 2020, Amnesty International's analytical report on the human rights situation in Europe and Central Asia in 2019 was presented. According to Amnesty International, in many Eastern European countries, the actions of the authorities in recent months have contributed to the loss of credibility of regional and international human rights institutions, while the governments of these countries have consistently violated citizens' rights to freedom of expression and assembly, as well as their social and economic rights.

According to Amnesty International, one example of such human rights violations was the right of the Prime Minister of Hungary, Viktor Orbán, to rule the country by decrees, bypassing parliament, amid the COVID-19 pandemic. As for Poland, human rights activists have strongly condemned the implementation, amid a pandemic, of plans to strengthen the law on abortion and amendments to the law on sex education in schools, which equate the concepts of "homosexuality" and "pedophilia." Today, "political and economic players in Central Asia, as well as in Eastern Europe, Russia and China, are using every means to shake up the international human rights system and the institutions designed to protect it," the Amnesty International's experts said.

However, given that the SARS-CoV-2 coronavirus was first detected in China in December 2019, many of the human rights violations mentioned in Amnesty International's 2019 report were recorded before the pandemic. At the same time, according to human rights activists, the right to freedom of expression in 2019 was not observed one hundred percent in any country in Eastern Europe and Central Asia. According to an Amnesty International's report, even in Ukraine, where there is a wide range of media, there have been regular attacks on journalists, which have been almost never thoroughly investigated.

In addition to restrictions on freedom of expression in Eastern European and Central Asian countries, human rights activists have been concerned about corruption, women's rights, environmental protection, and the right to free and fair elections. 
Minor refugees from camps on the Turkish-Greek border are sent by bus to Luxembourg and Germany. Refugees and members of certain marginalized groups, such as the homeless or Gypsies, have been most vulnerable to the COVID-19 pandemic.

Speaking about refugee camps on the Turkish-Greek border, experts emphacize on a catastrophic outbreak, due to the crisis caused by the coronavirus pandemic, the policy of protecting national borders from refugees in the European Union has only intensified.

As for Germany, in an effort to limit the spread of COVID-19, Germany closed the borders to all foreigners, with rare exceptions on March 16. Today, only doctors and foreigners traveling for professional reasons can enter Germany from neighbouring EU member states. The refugees who do not show obvious signs of coronavirus infection at the time of crossing the German border can also enter the country without hindrance. Even in a pandemic, people who have left their homes in search of protection should be able to apply for asylum in the EU. However, subject to the conditions that are now necessary in terms of health policy.

Migrants with symptoms of the disease should be subject to the same quarantine measures as the country's population, the expert said. Under these measures, refugees who are now being evacuated from Greece by Germany (Germany has agreed to accept 50 children and adolescents from refugee camps on the Turkish-Greek border) must first be quarantined for 14 days.

Severe restrictions on human rights, as well as restrictions on social support for citizens, have led to internal unrest as well as interstate armed conflicts (Figure 1).

Thus, the Libyan National Army (LNA) stops fighting against the forces of the Government of National Accord (GNA) for humanitarian reasons against the background of the pandemic of COVID-19 coronavirus infection. Martial law and mobilization have been declared in Azerbaijan and the NKR. Artillery, tanks, and air force are used in battles, McInnis (2020) says.

So far, Syria, which is also active in hostilities, have been able to avoid COVID-19 infection. However, the Syrian authorities continue to take measures to prevent the penetration of the dangerous virus into the country, in particular, they are preparing places to quarantine people entering the country. No cases of infection have been reported in Yemen, where hostilities are taking place between the rebels and a military coalition led by Saudi Arabia. However, the world's largest humanitarian catastrophe began against the background of hostilities in the country. According to the UN, about $80 \%$ of Yemen's population will not be able to survive in such conditions without humanitarian aid (Mintz, 2020). 
Petro P. Pidyukov, Alexander G. Kolb, Oleh V. Batiuk, Ihor H. Kudria y Larysa S. Tarasiuk National security policy: Changing priorities in the face of the COVID-19 threat

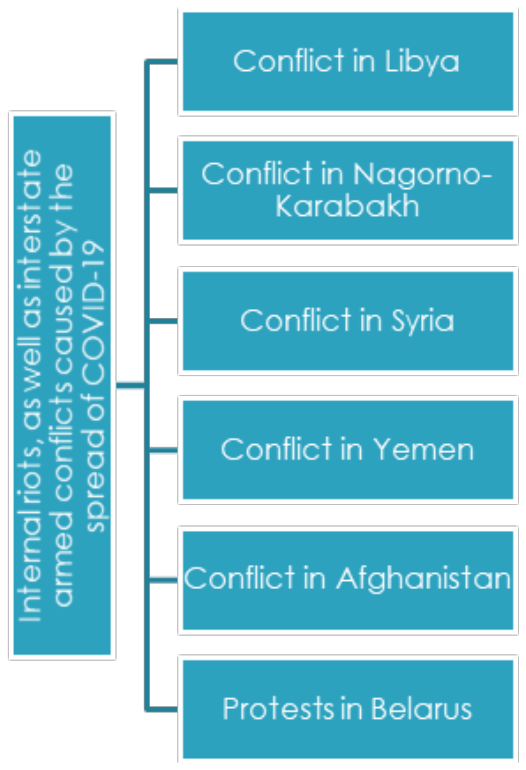

Figure 1. Internal riots, as well as interstate armed conflicts caused by the spread of COVID-19. Developed by the author on the basis of the scientific literature review.

Even the impending danger of COVID-19 did not force most of the warring parties to cease hostilities. In early March, the Riyadh-led coalition said it had prevented an attack by the Hussites on an oil tanker in the Arabian Sea. A few days after the statement, the Arab coalition struck a number of targets in the Yemeni port of Salif, according to representatives of the coalition forces.

The number of COVID-19 carriers is growing in Afghanistan as well, while the country will continue the war - the Afghan government announced the resumption of hostilities against the Taliban on March 19.

The protests began in May 2020 in Belarus on the eve of the next presidential election. On election day, August 9, 2020, immediately after the vote, mass protests began throughout Belarus. During the protests, violence was used against the protesters, dead and missing people appeared. Strikes took place at some enterprises. 


\section{Discussion}

The obvious threats of social and humanitarian catastrophes have become the basis for integration processes in Europe - EU leaders have agreed on five key priorities in joint action to overcome the crisis caused by the new coronavirus pandemic.

The first concerns the continuation of measures and the coordination of Member States' efforts to limit the spread of the virus. It is first necessary to strengthen the health care system. The World Health Organization's (2020) Regional Office for Europe Technical Recommendations were developed for this purpose (Figure 2).

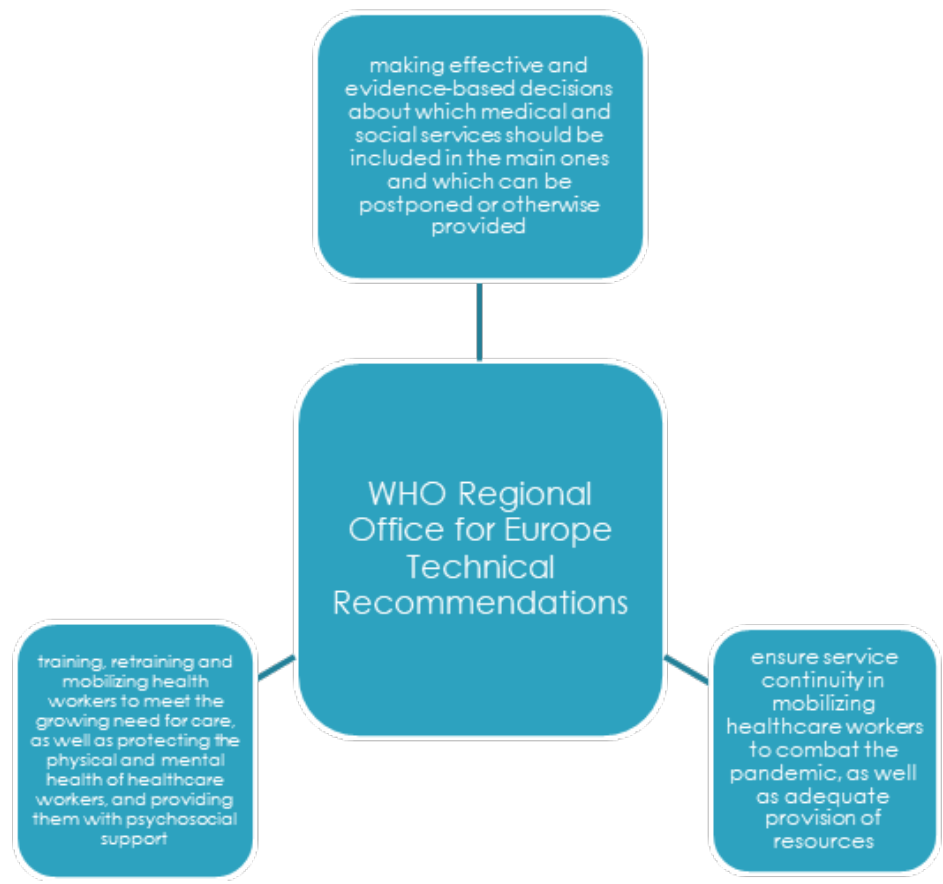

Figure 2. WHO Regional Office for Europe recommendations

The Technical Recommendations provide 10 strategic steps focused on practical solutions that will help healthcare service planners and healthcare system administrators in the region to ensure service continuity in mobilizing healthcare workers to combat with a pandemic, as well as adequate provision of resources. 
The list of basic health services includes: scheduled vaccination; reproductive healthcare services, including during pregnancy and childbirth; assistance to infants and the elderly; management of mental disorders, non-communicable diseases and infectious diseases such as HIV, malaria and tuberculosis; critical surgical interventions in the hospital; emergency care; palliative and hospice care; ancillary services such as basic diagnostic imaging, laboratory services and blood bank services.

To implement global measures to disseminate COVID-19, WHO has also updated practical planning guidelines, with an emphasis on supporting the reorganization and maintenance of universal access to quality basic healthcare services. The guidelines emphasize the importance of timely information support. Such information support requires regular and open communication, as well as active interaction with the public, to maintain people's trust in a system that can safely meet their basic needs and provide infection control in healthcare facilities - in which case people will continue to seek help and follow the recommendations of healthcare facilities.

The second priority is to coordinate efforts at the level of both the international community and national governments to provide the necessary medical equipment that countries need to fight the virus (Figure 3).

The amount of funds allocated by different countries to combat coranovirus in \% to GDP

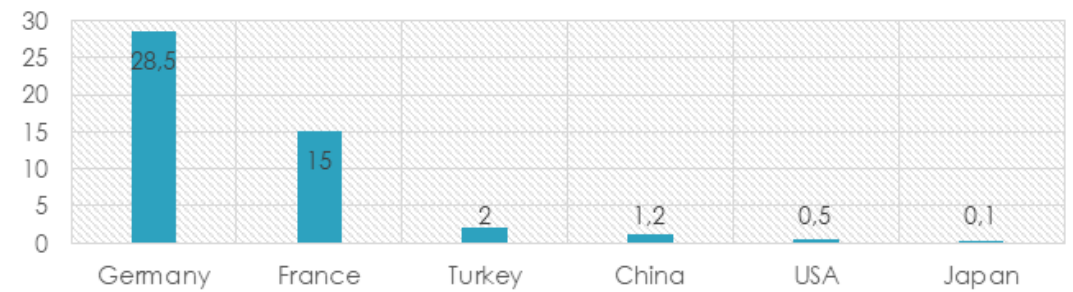

Figure 3. Coronavirus bailouts: Which country has the most generous deal? (BBC News, 2020)

The third priority is to coordinate efforts to support research to accelerate the development of a coronavirus vaccine. 
G. F. Foundation limited provides financial and organizational support to COVID-19 vaccine developers. The Coalition for Epidemic Preparedness Innovations (CEPI) is organizing a $\$ 2$ billion global fund for the rapid development and testing of candidate vaccines, and predicts that the first clinical trial data will be available by the end of 2020. On May 4, 2020, the WHO organized a telethon to raise $\$ 8.1$ billion in contributions from forty countries to support the development of vaccines to prevent COVID-19. At the same time, the WHO has also announced the deployment of an international "solidarity trial" to simultaneously evaluate several candidate vaccines reaching Phase II to III clinical trials.

In September, CEPI researchers reported that 9 different technology platforms had conducted research and development during 2020 to create an effective vaccine against COVID-19. According to CEPI, most vaccine development platforms undergoing clinical trials as of September target the coronavirus spike protein. The platforms being developed in 2020 include nucleic acid (RNA and DNA) technologies. Many vaccines being developed for COVID-19 are not similar to those already used to prevent influenza, but use "next-generation" strategies to pinpoint the mechanisms of COVID-19 infection. Samples of vaccines being developed may increase the flexibility of antigen manipulation and increase the effectiveness of COVID-19 infection control mechanisms in vulnerable subgroups of the population, such as healthcare workers, the elderly, children, pregnant women, and people with weakened immune systems.

The fourth area of joint efforts is to address economic issues, as the crisis that has hit Europe and the world has economic and social consequences. As part of the EU Recovery Plan, the European Commission (2020) has made adjustments to its Work Program for this year in response to the unprecedented reality of the coronavirus. The revised Work Program provides the financial, social and information basis for the recovery of Europe (Figure 4). The fifth key priority is the repatriation of European citizens who are currently in third countries and want to return home. 
Petro P. Pidyukov, Alexander G. Kolb, Oleh V. Batiuk, Ihor H. Kudria y Larysa S. Tarasiuk

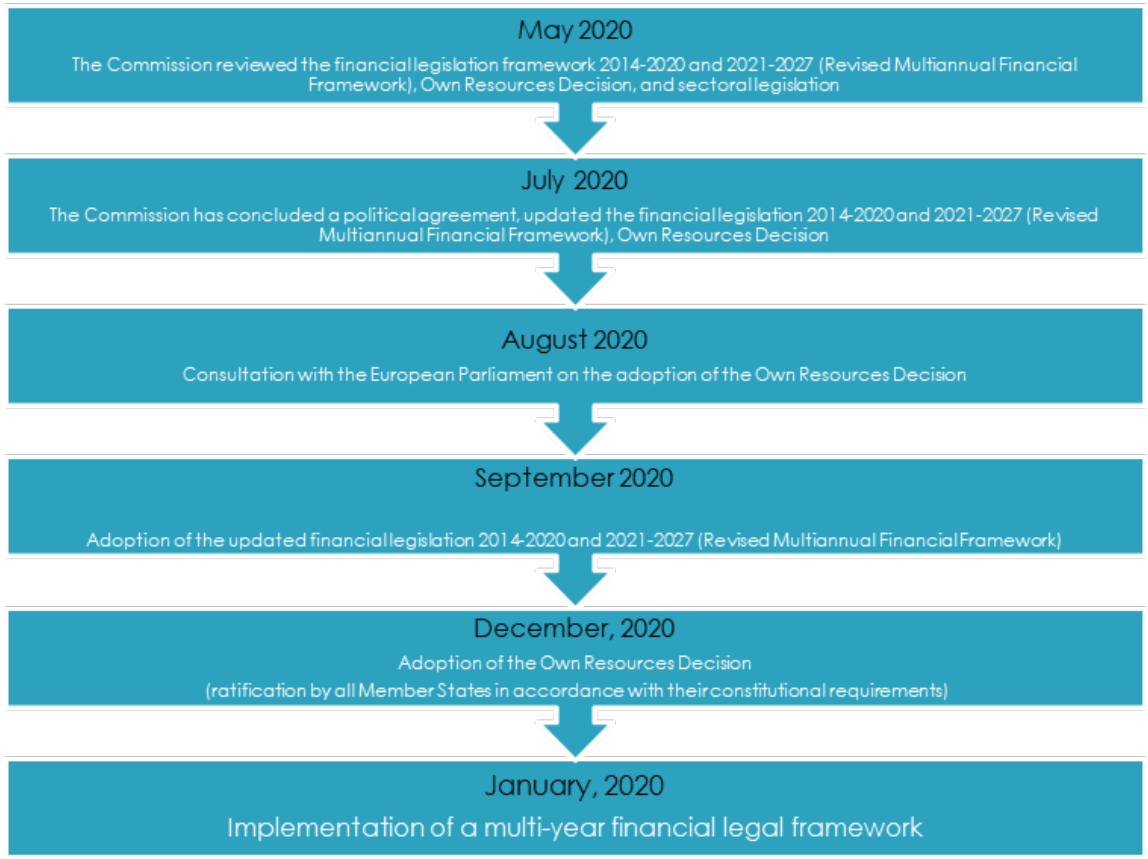

Figure 4. Stages of implementation of the Work Program for 2020

\section{Conclusions}

The most important lesson that the COVID-19 pandemic has taught the world is the need to work together to address the problems that affect all of humanity. Working together, we are capable of more than acting alone. The world order began to change long before the crisis of the COVID-19 pandemic. The coronavirus has only accelerated the key geopolitical trends on which the new world order that awaits us on the other side of the pandemic will be built, including deglobalization, China's geopolitical rise, severe restrictions on human and civil rights, intensified interstate armed conflict and domestic protests.

Based on the study, we identify the main geopolitical trends which will be the basis for building the new world order:

The first trend is deglobalization: material and technical difficulties that arose during the current crisis already indicate the gradual abandonment of the use of global production and sales ties, which ensure timely delivery. 
Moreover, as economic problems grow, the growing influence of nationalism and politics under the slogan "my country above all" will inevitably push companies to localize their business and give preference to national and regional cooperation.

The second trend is China's geopolitical rise, despite the fact that China has successfully secured the status of an economic and technological superpower, none expected the country to become a "soft" superpower. The current crisis could change this situation if China's crisis diplomacy continues and supports the position that measures taken by Beijing in response to the pandemic outbreak have been more effective than those taken in other countries. Of course, China's success alone does not mean that the situation in the country is slightly better than abroad. Statistics published by China raise reasonable doubts about the world community. The general distrust is due to China's attempt to hide information about the coronavirus outbreak, which contributed to its spread around the world. Donald Trump and his administration use this information as an election campaign strategy, as well as to divert attention from the results of their fight against the pandemic. However, China will not leave it at that, so there is a high probability that a new Cold War will break out after the current pandemic, this time between the United States and China. Regardless of whether a new world order is formed, there are things in the world that do not change.

\section{Limitations}

The complexity of scientific research is due to the fact that, on the one hand, it is impossible to conduct a comparative analysis without theoretical data, on the other - it is impossible to form an integrated concept without the empirical results of the analysis. In addition, there are many problems of theoretical and methodological nature, in particular, the problem of comparative analysis: "many cases - few variables", the bias of selection, Galton's analytical neutrality, which must be solved to ensure quality comparative research.

In turn, the diversity of research is explained by the fact that there are different comparative forms of research (case studies, binary studies, cross-temporal and cross-regional studies (Halytskyh, 2020), as well as various research strategies - with a focus on theoretical data and with a focus on empirical data (Muggah and Steven, 2020), which differ in both methodological and empirical efficiency, and are used in the comparative analysis of forms of government. 
Petro P. Pidyukov, Alexander G. Kolb, Oleh V. Batiuk, Ihor H. Kudria y Larysa S. Tarasiuk

\section{Bibliographic References}

BARNO, David; BENSAHEL, Nora. 2020. After the pandemic: America and national security in a changed world. Available online. In: https://bit. ly/2AovmNa. Consultation date: 27/06/2020.

BBC NEWS. 2020. Coronavirus bailouts: Which country has the most generous deal? Available online. In: https://www.bbc.com/news/ business-52450958. Consultation date: 15/07/2020.

BECKER, Sophia; MÖLLING, Christian; SCHÜTZ, Torben. 2020. "Deterrence and defense in times of covid-19: Europe's political choices" In: German Council on Foreign Relations Policy Brief. Vol. 9, pp. 2-9.

BIETTI, Elettra; KALTHEUNER, Frederike; TICKELL, Phoebe; TSENG, Francis; VAISMAN, Daria. 2020. The pandemic as a portal: tracking and enabling new possibilities. Available online. In: https://cyber.harvard. edu/events/virtual-pandemic-portal. Consultation date: 27/06/2020.

EUROPEAN COMMISSION. 2020. 2020 commission work programme. Available online. In: https://ec.europa.eu/info/publications/2020commission-work-programme-key-documents_en. Consultation date: 15/07/2020.

FINLEY, Alex; MENDEZ, Jonna; PRIESS, David. 2020. How do you spy when the world is shut down? Available online. In: https://bit.ly/38ilhhc. Consultation date: 27/06/2020.

FLEMING, Jeremy. 2020. GCHQ: Intelligence and cybersecurity today. Available online. In: https:/www.cheltenhamfestivals.com/science-/ whats-on/2020/gchq-intelligence-and-cybersecurity-today/. Consultation date: 27/06/2020.

FRIEDRICH-VACHE, Heidi; ENDRES-REICH, Daniela. 2020. Tax measures in the EU and other countries against the effects of coronavirus (SARS-CoV-2). Available online. In: https://www.roedl.com/insights/ covid-19/vat-ta-X-eu-commission-survey-measures-initiative-a-gainstcoronavirus. Consultation date: 15/07/2020.

FUKUYAMA, Francis. 2020. The pandemic and political order: it takes a state. Available online. In: https://fam.ag/2AmZo5m. Consultation date: 15/07/2020.

HALYTSKYH, Vitaliy. 2020. Loans, payroll and tax holidays: how the EU is saving businesses from the Corona crisis. Available online. In: https://www.eurointegration.com.ua/articles/2020/03/17/7107626/. Consultation date: 15/07/2020.

HEGEL, Georg. 2001. Philosophy of right. Batoche Books Ltd. Ontario, Canada. 
LUND, Susan; ELLINGRUD, Kweilin; HANCOCK, Bryan; MANYIKA, James. 2020. COVID-19 and jobs: Monitoring the US impact on people and places. Available online. In: https://www.mckinsey.com/industries/ public-and-social-sector/our-insights/covid-19-and-jobs-monitoringthe-us-impact-on-people-and-places\#. Consultation date: 27/06/2020.

MCINNIS, Kathleen. 2020. COVID-19: potential implications for international security environment - overview of issues and further reading for congress. Available online. In: https://www.everycrsreport.com/ reports/R46336.html. Consultation date: 15/07/2020.

MINTZ, Steven. 2020. Historical context: the global effect of World War I. Available online. In: https://www.gilderlehrman.org/history-resources/ teaching-resource/historical-context-global-effect-world-war-i. Consultation date: 15/07/2020.

MUGGAH, Robert; STEVEN, David; TORRES, Liv. 2020. We urgently need major cooperation on global security in the COVID-19 era. Available online. In: https://www.weforum.org/agenda/2020/04/ we-need-major-cooperation-on-global-security-in-the-covid-19-era/. Consultation date: 15/07/2020.

PHILIPS, Toby. 2020. A roadmap for digital-led economic development. Available online. In: https://bit.ly/3ga5rru. Consultation date: 27/06/2020.

SHEVCHUK, Oksana; MENTUH, Nataliya. 2020. "Tax benefits as an element supporting economic entities in the period of combating COVID-19: comparative and legal aspect” In: Analizy i Studia CASP. Vol. 1, pp. 21-31.

SLAUGHTER, Anne-Marie. 2020. Redefining national security for the postpandemic world. Available online. In: https://www.aspistrategist. org.au/redefining-national-security-for-the-post-pandemic-world/. Consultation date: 15/07/2020.

SUSSKIND, Daniel. 2020. A world without work: technology, automation, and how we should respond. Metropolitan Books. New York, USA.

SUSSMAN, Bruce. 2019. The list: best and worst countries for cybersecurity. Available online. In: https://bit.ly/3ePh8nb. Consultation date: 27/06/2020.

WORLD HEALTH ORGANIZATION. 2020. WHO Regional Office for Europe recommendations on influenza vaccination for the 2020/2021 season during the ongoing COVID-19 pandemic. Available online. In: https://apps.who.int/iris/bitstream/handle/10665/335721/WHOEURO-2020-1141-40887-55342-eng.pdf?sequence $=1$ \&isAllowed $=\mathrm{y}$. Consultation date: 15/07/2020. 

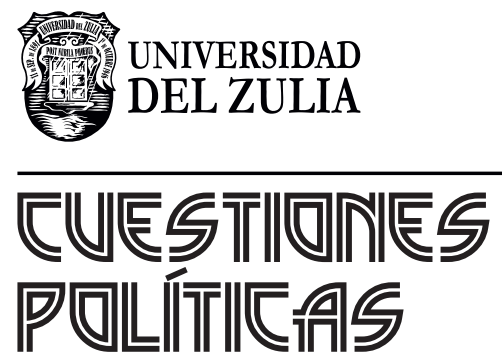

Vol.39 No 69

Esta revista fue editada en formato digital y publicada en julio de 2021, por el Fondo Editorial Serbiluz, Universidad del Zulia. Maracaibo-Venezuela 